\title{
Analysis and projection of global iron ore trade: a panel data gravity model approach
}

\author{
Robert Lundmark ${ }^{1}$
}

Received: 16 August 2017 / Accepted: 25 October 2017 /Published online: 8 November 2017

(C) The Author(s) 2017. This article is an open access publication

\begin{abstract}
In this study, an empirical model of global trade in iron ore is developed and applied. The empirical specification is based on the trade gravity theory in which the trade is determined by the income of the trading countries, the distance between the countries, and other characteristics of the countries. The model is specified allowing for country-specific effects. The estimation is performed with panel data for global bilateral iron ore trade flows from 1980 to 2016 including 121 countries and almost 14,000 observations. The results indicate a strong support of the gravity model hypotheses. On average, the trade value is projected to increase by approximately $5 \%$ per year up until 2035. The trade potential of iron ore is estimated to 410 million USD per year. Applied to forecasting and policy analysis, the results represent another worthwhile source of information providing an alternative view of the global trade in iron ore that can be helpful for decisionmakers.
\end{abstract}

Keywords Iron ore $\cdot$ Trade $\cdot$ Gravity model $\cdot$ Projection . Potential

Electronic supplementary material The online version of this article (https://doi.org/10.1007/s13563-017-0125-8) contains supplementary material, which is available to authorized users.

Robert Lundmark

robert.lundmark@1tu.se

$1 \quad$ ETS/Economics, Luleå University of Technology, SE-971 87 Luleå, Sweden

\section{Introduction}

In 2015 , almost $63 \%$ of the global iron production was exported to a value of more than 65.4 billion USD (UN 2017). This is an increase in real value by more than $500 \%$ compared to 1980 . The production, consumption, and trade patterns of iron ore have also changed over the last decades. Since 1980, the focus of trade has shifted from Europe and North America markets towards Asian and South American markets. But even within these markets, there have been major changes. For instance, China has replaced Japan as the major importer of iron ore in Asia while Brazil has replaced Canada as a major exporter. In addition, most European countries have experienced reduced shares of the trade value. These insights give raise to several interesting and important research questions. What have been the main drivers behind the changes in trade patterns? How will the future trade pattern change? Which countries will be the relative winners of these changes? What is the trade potential in iron ore? The objective of this paper is to apply a trade gravity model on the global iron ore trade in order to project and assess future trade patterns and trade potentials for iron ore.

The trade gravity model is commonly used to evaluate and predict trade patterns. The model has been applied in numerous specifications and contexts and it has been argued that the gravity model is the leading empirical model in economics regarding international trade flow (Anderson 2011). The basic trade gravity equation states that the trade flow between countries depends primarily on the size of the economy of the two countries, the distance between them. It has been applied to 
macroeconomic issues dealing with aggregate trade flows and, e.g., the effects of currency unions (e.g., Frankel and Rose 2002; Glick and Rose 2002; Berger and Nitsch 2008). It has also been applied to disaggregated trade flows, such as agricultural commodities trade (e.g., Zahaniser et al. 2002; Peterson et al. 2013) and forest products trade (e.g., Buongiorno 2015, 2016; Olofsson et al. 2017). In addition, the gravity model has been discussed in the context of cultural factors affecting trade (e.g., Hofstede 1994; Kogut and Singh 1998) and political factors (e.g., Srivastava and Green 1986). However, despite the importance of trade for the iron ore industry and the explanatory power of the gravity model, only a few studies have been found that quantitatively analyze the effects of globally changing economic conditions using gravity equations. Robertson and Robitaille (2014) investigate the importance of geography for trade in iron ore by estimating a gravity model. They show that iron ore has high trade elasticity with respect to distance. Moreover, Babri et al. (2017) separate the trade flow of iron ore into a long-term contract bound part and into a spot market (choice theory) part, using a gravity model.

\section{Global iron ore trade}

Figure 1 depicts the development of trade value and quantity for iron ore between 1980 and 2016. In 2016, the global export trade value of iron ore was 54,319 million USD (constant 2005 value). This is an increase by almost 1000 million USD compared to the year before and more than a fivefold increase compared to 1980 (UN 2017). As seen in the figure, the trade value peaked 2011 after a sharp increase starting around 2004. Between 1980 and 2004 the trade value was fairly constant. The sharp increase and decline in trade value is contrasting with the steady increase in traded weight. During the whole period, the trade in iron ore increased from 215 to 1496 million ton per year.
The decline in trade value after 2011 can be explained by a number of interacting factors. Firstly, until 2005 the price of iron ore was fairly constant with a system of annual contracts keeping the price volatility down. Now, the pricing system is based on more flexible monthly contracts and spot markets. As a consequence, price fluctuations that used to occur over a matter of months now occur over a matter of days. Secondly, the decline in trade value coincides with an equally large decline in iron ore price. In turn, the price decline can partly be explained by the sagging demand growth from the Chinese steel industry. Since its peak in 2011, the iron ore price has declined by more than two thirds.

In terms of export value, Australia is the by far largest exporter and accounted for almost $59 \%$ of the global export value. Brazil is on a remote second place and accounted for approximately $20 \%$. South Africa, Canada, and Sweden follow with five, four, and $2 \%$, respectively. In the import side, Chine accounts for almost $71 \%$ of the trade value followed by Japan, Korea, and Germany with nine, five, and $3 \%$, respectively. Thus, both in terms of export and import there are only few countries that account for the majority of the trade.

Iron ore is usually considered a heterogeneous commodity. It is predominantly mined as magnetite $(72.4 \%$ $\mathrm{Fe})$ and hematite $(69.9 \% \mathrm{Fe})$ and traded as sinter or pellets. Ores containing very high quantities of hematite or magnetite are known as "natural ore" or DSO "direct shipping ore" and can be fed directly into iron-making blast furnaces. Iron ore can also be pre-treated before traded. For instance, sinter feed is made from DSO and pellets are made by taking very fine iron ore and agglomerating them with moisture and a binder to form balls. Pellets are essentially artificial lump. The technical specification of the individual steel mills sets the restriction of the type of iron ore that can be used. But on an aggregate level, the demand of iron ore is still a derived demand suggesting that it is the demand for steel products that are the main determinants of trade.
Fig. 1 Global trade value and traded weight of iron ore and concentrate 1980-2016 (million constant 2005 USD and million tons). Source: UN (2017)

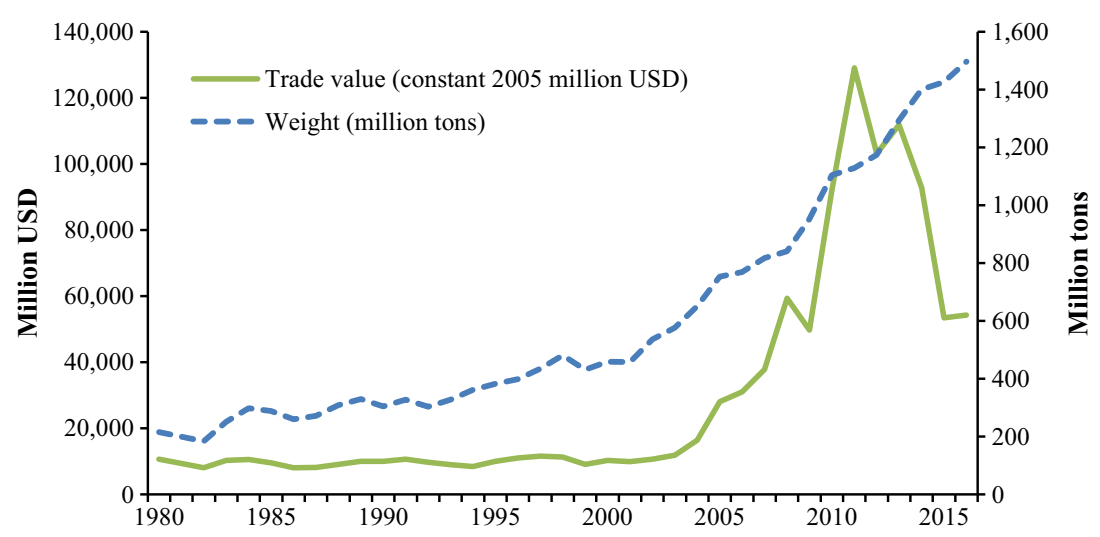




\section{Trade gravity model}

The first application of the gravity model on trade flows was by Tinbergen (1962) but it was not until 1995 it entered mainstream of trade research. Head and Mayer (2013) describe the latter development as three distinct steps: First, the realization that previous models could not explain "missing" trade (Trefler 1995). Second, the research on multilateral resistance/fixed effects established theoretical relationships between gravity models and, e.g., monopolistic competition and Armington and thus connecting the gravity model to solid micro-foundations (Anderson and van Wincoop 2003). It became clear that fixed effects could be used to capture multilateral resistance terms that emerged from different theoretical models (Redding and Venables 2004). The final step was the convergence of the literature on gravity models and heterogeneous firms (Chaney 2008). This work suggested changes in how the gravity equations should be estimated and how the estimated coefficients should be interpreted. Gravity model, used in an economic context, were initially criticized for lacking theoretical foundations (Deardorff 1984). However, the theoretical foundation of the gravity model has been developed and can now be considered consistent with microeconomic foundations. This work started with Anderson (1979) and has continued since. The structure of the gravity model can be derived under different theoretical frameworks, e.g., Ricardian (Eaton and Kortum 2002); HeckscherOhlin (Evenett and Kneller 2002) and models based on increasing returns and product differentiation (Bergstrand 1989). Because of the flexibility of the gravity model, its empirical success does not per se provide support for any particular model of trade. As with most empirical models, the trade gravity model also has limitations. Most prominent among the limitations are that trade costs of third parties are not considered important and do not affect the trade between two trading partners. Another limitation is that trade creation and diversion cannot be captured by the gravity model alone.

In its most basic form the trade gravity model stipulates that trade flows between trading partners vary positively with the magnitude of the partners' economic activities and negatively with the distance between them. Thus, the basic relationship can be expressed as:

$T_{i, j}=A_{i}\left(\frac{Y_{i}^{\beta_{1}} Y_{j}^{\beta_{2}}}{D_{i, j}^{\beta_{3}}}\right)$

where $T$ is the trade flow in monetary terms for trading partner $i$ and $j, A$ is a constant (across cross sections), $Y$ is the magnitude of the economic activity, $D$ is the distance, and the $\beta$ 's are unknown parameters. In this specification, possible third-country effects, if any, must be captured indirectly via either the exporting or the importing country. Eq. 1 can be linearly estimated by transforming the equation into logarithmic form. ${ }^{1}$

In general, and for previously evaluated traded commodities, the trade gravity model has made good predictions. Feenstra et al. (2001) conclude that with no entry barriers, export is more sensitive to changes in domestic income than on changes in trading partners' income. In a later study, Stay and Kulkarni (2016) test the validity of the gravity model by examine United Kingdom (UK) and its trading partners. More specifically, they investigate how the trade flow between UK and its trading partners is influenced by colonial history and membership in the European Union. They conclude that the gravity model is good at predicting the trade flows. McCallum (1995) used the gravity equation to refute the notion that national borders had lost their economic relevance and estimated the effects of trade integration policies and the understanding of "border effects". There have also been a few attempts to apply the gravity model on forestry products. Among the first empirical studies are Kangas and Niskanen (2003) who analyzed trade in forest products between EU and central and eastern European countries (CEE) by using a gravity model. The data include trade between $15 \mathrm{EU}$ and ten CEE countries and has 498 observations. The result showed that the trade and production of forestry products under the 1990s increased in CEE countries. According to estimates with the gravity model, the trade between EU countries and CEE countries did not reached its expected value. Later, Akyüz et al. (2010) examines the trade with forestry products between Turkey and the EU countries using a gravity model. They used panel data for the period 2000-2006. The results indicate that Turkey is below its potential export with EU countries and they conclude that it would be beneficial for both Turkey and EU if Turkey joins EU. Buongiorno (2015) analyzed if the introduction of the European monetary union had any effect on the trade flow of forestry products. He applies a gravity model on three forest products using a panel data on bilateral trade between 12 Euro-countries for the time period 1988-2013. By applying the gravity model in differential form, the time-invariant effects, e.g., distance between countries and common borders, was eliminated. The model was estimated using fixed effects. He found that trade increased for all products and countries after the introduction of the monetary union. In a later study, Buongiorno (2016) studied forestry product trade flow and made forecasts of the value of trade between member

\footnotetext{
${ }^{1}$ The multiplicative form of the gravity equation is not a necessary condition. Both linear demand systems (Ottaviano et al. 2002) and translog form (Novy 2013) has been used.
} 
countries in Trans-Pacific Partnership (TPP) for the same forest products as in Buongiorno (2015). The data used is a panel of TPP participant for the period 2005-2014. The model was estimated using both fixed and random effects, resulting in similar results. The trade in all three forest products were positively affect by the TPP.

\section{Data}

The unbalanced panel includes 13,969 observations divided between 121 countries and for the period 1980-2016. The panel is unbalanced in the sense that not all cross sections have the same number of time periods. The trade variable is monetary and measuring trade value converted into constant 2005 USD and downloaded from UN Comtrade Database under SITC (rev.2) for iron ore and concentrates (commodity code 281) (UN 2017). Observations with a trade value less than 1000 USD has been removed from the sample. The GDP and distance variables are obtained from CEPII (2017). Observations and projections for the GDP variables are summarized from the EconMap 2.4 Reference (Fouré et al. 2012, 2013). Three GDP variables are available: GPD in million constant 2005 USD; GDP in 2005 PPP per capita and GDP in million current USD. The distances between any two countries are summarized in the bilateral GeoDist database (Mayer and Zignago 2011). The database contains two simple and two weighted distance variables. The two simple measures are based on (1) latitudes and longitudes of the most important cities (in terms of population)

Table 1 Descriptive statistics and correlation matrix

\begin{tabular}{lllll}
\hline & Mean & Std. dev. & Min & Max \\
\hline Trade value $^{\mathrm{a}}$ & 80.8 & 1020 & 0.001 & 51,000 \\
Distance $^{\mathrm{b}}$ & 5315 & 4850 & 59.6 & 19,297 \\
Exporter $_{\quad \text { GDP }}^{\mathrm{c}}$ & $1,253,397$ & $2,302,888$ & 1097 & $14,700,000$ \\
$\begin{array}{l}\text { Importer } \\
\quad \text { GDP }^{\mathrm{c}}\end{array}$ & $1,165,809$ & $2,171,323$ & 413 & $14,700,000$ \\
& & & & \\
& Trade value & Distance & Exporter & Importer \\
& & & GDP & GDP \\
$\begin{array}{l}\text { Trade value } \\
\text { Distance }\end{array}$ & 1.00 & & & \\
Exporter & 0.07 & 1.00 & & \\
$\quad-0.01$ & 0.07 & 1.00 & \\
GDP & & 0.13 & -0.04 & 1.00 \\
$\quad$ GDP & 0.08 & & & \\
\hline
\end{tabular}

${ }^{\text {a }}$ Million constant 2005 USD

${ }^{\mathrm{b}}$ Distance between important cities

${ }^{\mathrm{c}}$ GDP million constant 2005 USD and (2) the distance between the geographical coordinates of the capital cities. From the same database information on common borders, language and colonial history is obtained, as dummy variables. The common border variable is set to unity if two countries are contiguous. Two common language measures are defined: (1) if the two countries have the same official language and (2) if at least $9 \%$ of the populations speak the same language. The final dummy variable is if two countries ever had a colonial link. The descriptive statistics and the correlation matrix for the continuous variables are presented in Table 1.

\section{Econometric issues}

In order to comply with the theoretical conditions of the gravity model, the multilateral resistance term need to be accounted for empirically. Initially, a remoteness variable was used as a proxy, but as the theory developed it became clear that it was a too weak proxy for the resistance term (e.g., Wei 1996; Helliwell 1998). Instead, it is now common practice to used fixed effects estimation. This does not impose strong structural assumptions on the model. Another, more practical advantage of using fixed effects is that intermediate trade destinations can be accounted for. That is, countries such as the Netherlands and Singapore have large imports but they re-export. Ideally, the exporter should also be the producer and the importer the consumer. But the world is more complicated than that. However, fixed effects can control for this since they account for any unobservable that contributes to shift of the overall level of exports or imports of a country.

Equation 1 is linearized by taking the logarithm and estimated with panel data from multiple bilateral trade flows between countries and years using fixed effects. Each observation is represented by the export value of iron ore between a county pair in a given year. By using the fixed effects approach it is assumed that the disturbance term can be expressed as $u_{i, j, t}=a_{i, j}+\varepsilon_{i, j, t}$ where $a_{i, j}$ is a constant for each bilateral trade flow. That is, $a_{i, j}$ measures the difference in exports for a particular country pair due to other variables than those explicitly in the model. The residual $\varepsilon_{i, j, t}$ is assumed i.d.d. with zero mean and constant variance across trade flows and years.

To test the validity of the assumptions, the fixed effects estimation is compared to random effects and OLS. The OLS model, under the assumption that the fixed effects are nil, can be rejected using an $F$ test. A Hausman test is conducted to evaluate random vs. fixed effects. The Hausman test rejects the null hypothesis that random effects are appropriate. Thus, both test support the use of the fixed effect approach. In addition, the countries being observed is not a random sample from a larger population, 
thus fixed effects approach seemed appropriate. Indeed random effects models are seldom used in gravity studies (Baier and Bergstrand 2007). The estimation is applied with robust estimation of the standard errors to account for possible heteroscedasticity or within-group correlation. Moreover, it is carried out with the Stata software using the xtreg, fixed effects option.

\section{Results}

The results are presented in three parts. First, the basic econometric results based on Eq. 1 using fixed effects are presented and discussed. Second, the estimated coefficients are used to simulate trade flow projections of iron ore up until the year 2035. Third, the trade potential is calculated.

Table 2 presents the regression results based on five model specifications (I-V). Models I-III is based on the basic specification, which is the logarithmic linearization of Eq. 1. Model II uses a squared distance variable compared to Model I that is using a normal distance variable. Model III is using GDP per capita instead of GDP as in Model I. The specification is expanded in Model IV and V by introducing multilateral resistance terms. In Model IV, a dummy variable for common language, common border and colonial links are added. Two definitions of common language are tested (individually) in the specification of Model IV: (1) a common official language and (2) if a common language is spoken by at least $9 \%$ of the population in both countries. The results of Model IV are based on the official common language definition (the other definition produced statistically insignificant results as well and is not presented). Finally, in Model V, common language and colonial links are dropped. Of the five specifications, we chose to continue the analysis using Model V. It might be pointed out that although most of the iron ore trade is seaborne, suggesting that a common land border might not be an important determinant for trade, the data consist of all bilateral trade flows of iron ore. In fact, the descriptive statistics of the common border dummy variable suggest that almost $17 \%$ of the observations (bilateral trade flows) occur between countries that share a common border. The inclusion of the common border dummy variable is also supported by findings in the previous literature.

The results based on Model V support the basic structure of the trade gravity model. The trade increases with the size of the trading partners' economies and decreases with the distance between them. More specifically, if the GDP of the exporting country of iron ore increases by $1 \%$, the trade flow value will increase by $0.64 \%$. Similarly, of the GDP of the importing country increases by $1 \%$, the trade flow value will increase by $0.48 \%$. The further apart the countries are, the less trade will they engage in. For each percentage increase in distance, the trade flow will be reduced by $0.32 \%$. Thus, in relative terms, the results suggest that the size of the economy has a larger effect on trade flow value than distance. Finally, the coefficient for the common border dummy suggests that if the trading countries share a common border (or more specifically, they constitute a continuous land mass) the trade flow value of iron ore will be 1.95 million USD $\left(e^{0.67}\right)$ higher per year than otherwise.

Table 2 Regression results

\begin{tabular}{|c|c|c|c|c|c|}
\hline & Model I & Model II & Model III & Model IV & Model V ${ }^{\mathrm{a}}$ \\
\hline Distance & $-0.46(0.97)^{* * *}$ & & $-0.32(0.01)^{* * *}$ & $-0.34(0.07)^{* * * *}$ & $-0.32(0.08)^{\text {**** }}$ \\
\hline Distance $^{\wedge} 2$ & & $-0.23(0.05)^{* * * *}$ & & & \\
\hline Exporter GDP & $0.62(0.34)^{*}$ & $0.62(0.34)^{*}$ & & $0.64(0.34)^{*}$ & $0.64(0.34)^{*}$ \\
\hline Importer GDP & $0.49(0.06)^{\text {***** }}$ & $0.49(0.06)^{* * * *}$ & & $0.48(0.05)^{* * * *}$ & $0.48(0.06)^{* * *}$ \\
\hline Exporter GDP/capita & & & $0.95(0.43)^{* *}$ & & \\
\hline Importer GDP/capita & & & $0.35(0.08)^{* * * *}$ & & \\
\hline Common border & & & & $0.74(0.29)^{* *}$ & $0.67(0.28)^{* * *}$ \\
\hline Common language & & & & $-0.35(0.33)$ & \\
\hline Colony & & & & $0.14(0.36)$ & \\
\hline Constant & $2.43(4.32)$ & $2.43(4.32)$ & $3.10(4.04)$ & $1.24(4.46)$ & $1.04(4.48)$ \\
\hline$F$ value & 37.98 & 37.98 & 15.40 & 22.61 & 31.58 \\
\hline Number of Obs & 13,969 & & & & \\
\hline Number of Groups & 121 & & & & \\
\hline
\end{tabular}

All continuous variables in logarithmic form

$*{ }^{* *},{ }^{* * *}$ represent statistical significance at 10,5 , and $1 \%$, respectively

${ }^{\mathrm{a}}$ Analyzed model 
Table 3 Trade projections (percent) with base year 2015 (million USD) until 2035

\begin{tabular}{llllll}
\hline & 2015 & $2020(\%)$ & $2025(\%)$ & $2030(\%)$ & $2035(\%)$ \\
\hline Australia & 35,910 & 27.2 & 26.6 & 25.6 & 23.5 \\
Bahrain & 395 & 17.3 & 12.4 & 10.0 & 8.8 \\
Brazil & 13,831 & 22.1 & 20.3 & 19.0 & 17.9 \\
Canada & 2714 & 16.2 & 15.5 & 15.4 & 15.6 \\
Chile & 707 & 26.0 & 23.5 & 22.5 & 21.3 \\
India & 205 & 31.1 & 29.3 & 28.5 & 27.1 \\
Indonesia & 30 & 27.7 & 25.3 & 24.6 & 22.8 \\
Kazakhstan & 404 & 23.2 & 20.2 & 19.0 & 18.7 \\
Malaysia & 497 & 32.0 & 28.6 & 27.0 & 25.2 \\
Mongolia & 227 & 39.4 & 35.4 & 35.0 & 32.8 \\
Netherlands & 12 & 11.7 & 11.1 & 10.7 & 10.9 \\
Norway & 164 & 14.2 & 12.4 & 10.8 & 9.8 \\
Oman & 285 & 23.2 & 14.4 & 9.1 & 7.2 \\
Peru & 349 & 34.1 & 31.1 & 29.1 & 26.7 \\
Philippines & 119 & 21.0 & 21.9 & 21.4 & 20.5 \\
Russia & 989 & 26.3 & 24.7 & 24.8 & 23.7 \\
South Africa & 2639 & 24.3 & 23.6 & 23.8 & 22.6 \\
Sweden & 1545 & 12.7 & 11.4 & 10.4 & 10.1 \\
Ukraine & 2027 & 28.8 & 29.7 & 32.1 & 30.4 \\
USA & 646 & 13.4 & 12.6 & 12.6 & 12.9 \\
\hline & & & & & \\
\hline
\end{tabular}

Table 4 Trade potential per year in million USD based on 2015 statistics
In general, these results can be compared with previous studies using the trade gravity model, albeit not for iron ore specifically since previous studies are lacking for iron ore. Head and Mayer (2013) make a metaanalysis of gravity models estimates based on 159 studies and more than 2500 estimates. Their results can be contrasted with the results for iron ore trade presented herein. For the structural gravity models they conclude that the average effect of origin GDP (exporter GDP) is 0.74 and of destination GDP (importer GDP) is 0.58 . These are similar results as for iron ore, both in magnitude and in relative ranking (i.e., exporter GDP has a larger effect than importer GDP). These results are in line with Feenstra et al. (2001) argument of home market effects. The average distance elasticity reported by Head and Mayer (2013) is - 1.1, which is lower than the results for iron ore trade. A plausible explanation could be that iron ore is mostly traded by sea transport making it less sensitive to distance compared to trade aggregates (or other specific goods and commodities) using land transportation modes. The contiguity effect (common border) is similar to that reported by Head and Mayer (2013). They estimate an average metaresult on 0.66, while the result for iron ore is 0.67. Overall, the results for iron ore seem to be in line with previous literature.

\section{Iron ore trade projections}

The iron ore trade projections are based on the estimated coefficients from Model V. Table 3 shows the projected 5-year incremental growth rates from 2015 to 2035 for the global iron ore trade. The table lists the total export from specific countries. The GDP projections are obtained from CEPII (2017). In addition, the observed export value of iron ore (million USD) for 2015 is presented in the table. The projections are based on bilateral trade observations higher than 30 million USD and are under the assumption that countries keep the same trading partners as it had during 2015. This delimitation is made in order to simply the calculations. The detailed trade projection calculations are presented in Table 5 in the Appendix.

As suggested by Table 3, we can expect the trade value of iron ore to increase in the future. In total, the annual average growth rate is expected to $5 \%$ initially, only to slowly decline over time and end up around $4.4 \%$ in 2035. However, even with a declining growth rate, the trade value is expected to increase over time. From 2020 , the annual trade value change is 3.19 billion USD, which increase to 3.52 billion in $2025,3.89$ billion in 2030 and 4.25 billion in 2035. This represents an accumulated increase in trade value on 85 billion USD for 
the time period. Labson (1997) made the projection that the iron ore demand would increase by approximately 122 million metric tons per year until 2000 of which China alone was predicted to account for $46 \%$ of the increase. He also concluded that Australia, Brazil and India were expected to further expand their production and export of iron ore. Australian production was projected to increase by 27.7 million tons, Brazil by 22.3 million tons and India by 15.1 million tons.

Mongolia is projected to have the highest rate of increase in trade value (albeit from low levels). Of the six countries that had an iron ore trade value higher than 1000 million USD in 2015 (Australia, Brazil, Canada, South Africa, Ukraine, and Sweden), Table 3 indicate that all but Ukraine will experience an increasing but diminishing growth rate. However, if their growth rate is expressed in relative terms to Mongolia's growth rate another picture emerges (see Table 6). Australia, Canada, South Africa, and Ukraine will have an increase growth rate in iron ore trade value relative Mongolia, while Brazil and Sweden will have a steady growth rate. This disparity can partly be explained by the GDP projections. Firstly, the economies are expected to increase suggesting that more iron ore will be trade to a higher total value. Second, the increase in GDP is not uniform; some countries are expected to have a fast GDP growth compared to other countries. This is reflected in the relative growth rate in iron ore trade value.

\section{Iron ore trade potentials}

Having estimated the gravity model for global bilateral trade flows of iron ore, we proceed to estimate the global trade potential for iron ore. The regression estimates give the prediction of the average trade level. This suggests that some trade flows trade more than average while other flows trade less. By applying the estimated coefficients, it is possible to calculate the potential trade by analyzing the difference between the observed trade flows and the estimated (i.e., the size of the error term), with the caveat that no new trade routes are established (c.f. Batra 2004). The interpretation of a large negative trade potential suggests that a country could be trading more based on their economic and geographical fundamentals. Something the model cannot explain is holding trade back. However, the trade potential needs to be interpreted carefully since the error term also include statistical noise and possible measurement errors. That is, it is important not to overemphasize the trade potential but rather use it as a first indication on particular trade relationships.

Tables 4, 5, 6 present the calculated trade potential based on 2015 statistics. Countries with a trade potential less than 1 million USD has been excluded from the table due to space limitation. Overall, the trade in iron ore has the potential to increase by 410 million USD per year. For individual countries, Germany, France, the USA, and the UK have the largest potential to increase their trade in iron ore.

\section{Conclusions}

The objective of this paper is to apply a trade gravity model on the global iron ore trade in order to project and assess future trade patterns and trade potentials for iron ore. In general, the gravity model for iron ore performed well and is in line with the theoretical prediction of the model. That is, countries in proximity to each other will trade more with each other than with counties further away and large economies tend to have a larger trade than small ones. The empirical results conform to the metaresults for gravity models, suggesting that the approach can be used to analyze global iron ore trade.

The estimated coefficients are expected values over a very large number of trade flows and years of observation. There was strong statistical evidence supporting the gravity hypothesis, but as indicated by the standard errors, there were substantial variations for individual trade flows and years. The development of the home market has a larger effect on the trade flow value compared to the development of foreign markets. This suggests that policies towards developing home markets will also have a positive effect on the trade value of iron ore.

The trade projections for iron ore suggest a continuous increase in the trade value. This is explained by the expected economic development in both the exporting and importing countries. On average, the trade value is projected to increase by approximately $5 \%$ per year up until 2035. However, like most econometric projections, such forecasts must be viewed cautiously since they are subject to large potential errors. The trade potential of iron ore is estimated to 410 million USD per year. Conclusions made from this result must also be made carefully. Rather, it might give an indication of the possible trade potential.

Despite the discussed limitations of the gravity model-limitations shared to a large extent with other approaches - it has the advantage of simplicity and transparency. All the data are readily available, and the results are easily reproduced. Applied to forecasting and policy analysis, the results represent another worthwhile source of information providing an alternative view of the global trade in iron ore hat can be helpful for decision-makers. 


\section{Appendix}

Table 5 Trade projections and relative development for 2015 existing bilateral trade in iron ore

\begin{tabular}{|c|c|c|c|c|c|c|c|c|c|c|}
\hline & & \multicolumn{5}{|c|}{ Projection (2015 million USD) } & \multicolumn{4}{|c|}{ Relative development } \\
\hline & & 2015 & $\begin{array}{l}2020 \\
(\%)\end{array}$ & $\begin{array}{l}2025 \\
(\%)\end{array}$ & $\begin{array}{l}2030 \\
(\%)\end{array}$ & $\begin{array}{l}2035 \\
(\%)\end{array}$ & $\begin{array}{l}2020 \\
(\%)\end{array}$ & $\begin{array}{l}2025 \\
(\%)\end{array}$ & $\begin{array}{l}2030 \\
(\%)\end{array}$ & $\begin{array}{l}2035 \\
(\%)\end{array}$ \\
\hline \multirow[t]{7}{*}{ Australia } & China & 29,095 & 29 & 28 & 27 & 25 & 77 & 79 & 78 & 77 \\
\hline & India & 16 & 26 & 26 & 26 & 24 & 66 & 72 & 74 & 74 \\
\hline & Indonesia & 131 & 18 & 18 & 18 & 17 & 47 & 52 & 53 & 53 \\
\hline & Japan & 3964 & 15 & 16 & 15 & 14 & 38 & 44 & 44 & 45 \\
\hline & Korea & 2658 & 22 & 22 & 21 & 20 & 58 & 61 & 60 & 60 \\
\hline & Singapore & 46 & 25 & 23 & 20 & 17 & 64 & 64 & 58 & 54 \\
\hline & Egypt & 28 & 23 & 20 & 19 & 18 & 60 & 56 & 55 & 57 \\
\hline \multirow[t]{6}{*}{ Bahrain } & India & 13 & 24 & 21 & 20 & 18 & 62 & 58 & 56 & 56 \\
\hline & Malaysia & 13 & 20 & 17 & 15 & 14 & 53 & 46 & 43 & 42 \\
\hline & Oman & 34 & 19 & 13 & 9 & 7 & 50 & 36 & 26 & 21 \\
\hline & Qatar & 89 & 24 & 16 & 12 & 10 & 62 & 44 & 35 & 31 \\
\hline & Saudi Arabia & 39 & 17 & 11 & 7 & 6 & 44 & 31 & 21 & 19 \\
\hline & $\begin{array}{c}\text { United Arab } \\
\text { Emirates }\end{array}$ & 179 & 12 & 8 & 6 & 6 & 32 & 24 & 19 & 18 \\
\hline \multirow[t]{29}{*}{ Brazil } & Argentina & 349 & 17 & 16 & 15 & 14 & 44 & 44 & 43 & 44 \\
\hline & Bahrain & 195 & 17 & 14 & 13 & 11 & 43 & 39 & 36 & 36 \\
\hline & Belgium & 170 & 13 & 12 & 12 & 11 & 35 & 34 & 34 & 35 \\
\hline & Canada & 13 & 16 & 15 & 14 & 14 & 42 & 42 & 41 & 44 \\
\hline & China & 6452 & 28 & 25 & 24 & 22 & 73 & 71 & 68 & 67 \\
\hline & Croatia & 15 & 18 & 17 & 17 & 16 & 47 & 48 & 48 & 50 \\
\hline & Egypt & 98 & 23 & 22 & 22 & 21 & 61 & 62 & 63 & 66 \\
\hline & France & 283 & 14 & 13 & 13 & 12 & 37 & 37 & 36 & 37 \\
\hline & Germany & 247 & 12 & 10 & 9 & 9 & 31 & 29 & 26 & 28 \\
\hline & India & 47 & 24 & 23 & 22 & 21 & 63 & 64 & 64 & 65 \\
\hline & Indonesia & 40 & 17 & 16 & 15 & 14 & 44 & 44 & 43 & 44 \\
\hline & Italy & 230 & 11 & 10 & 9 & 9 & 29 & 28 & 26 & 28 \\
\hline & Japan & 1209 & 13 & 13 & 12 & 12 & 34 & 36 & 35 & 36 \\
\hline & Korea & 501 & 21 & 19 & 18 & 17 & 54 & 53 & 51 & 51 \\
\hline & Libya & 27 & 19 & 15 & 11 & 10 & 51 & 41 & 31 & 31 \\
\hline & Malaysia & 767 & 21 & 19 & 17 & 17 & 54 & 52 & 50 & 51 \\
\hline & Mexico & 28 & 19 & 18 & 16 & 15 & 49 & 49 & 46 & 47 \\
\hline & Netherlands & 819 & 14 & 13 & 12 & 11 & 35 & 35 & 33 & 34 \\
\hline & Oman & 376 & 20 & 15 & 11 & 10 & 51 & 41 & 33 & 30 \\
\hline & Philippines & 490 & 23 & 22 & 21 & 20 & 60 & 63 & 62 & 63 \\
\hline & Qatar & 104 & 24 & 18 & 15 & 13 & 63 & 50 & 43 & 40 \\
\hline & Romania & 33 & 20 & 18 & 17 & 15 & 51 & 49 & 48 & 47 \\
\hline & Saudi Arabia & 164 & 18 & 13 & 10 & 9 & 46 & 36 & 27 & 27 \\
\hline & South Africa & 28 & 18 & 17 & 17 & 16 & 46 & 48 & 49 & 50 \\
\hline & Spain & 160 & 14 & 13 & 12 & 12 & 36 & 37 & 36 & 36 \\
\hline & Trinidad and Tobago & 155 & 25 & 22 & 20 & 19 & 66 & 63 & 59 & 58 \\
\hline & Turkey & 191 & 22 & 20 & 19 & 18 & 57 & 56 & 54 & 55 \\
\hline & USA & 142 & 14 & 13 & 13 & 12 & 37 & 37 & 36 & 38 \\
\hline & $\begin{array}{c}\text { United Arab } \\
\text { Emirates }\end{array}$ & 225 & 13 & 10 & 9 & 8 & 33 & 29 & 25 & 26 \\
\hline
\end{tabular}


Table 5 (continued)

\begin{tabular}{|c|c|c|c|c|c|c|c|c|c|c|}
\hline & & \multicolumn{5}{|c|}{ Projection (2015 million USD) } & \multicolumn{4}{|c|}{ Relative development } \\
\hline & & 2015 & $\begin{array}{l}2020 \\
(\%)\end{array}$ & $\begin{array}{l}2025 \\
(\%)\end{array}$ & $\begin{array}{l}2030 \\
(\%)\end{array}$ & $\begin{array}{l}2035 \\
(\%)\end{array}$ & $\begin{array}{l}2020 \\
(\%)\end{array}$ & $\begin{array}{l}2025 \\
(\%)\end{array}$ & $\begin{array}{l}2030 \\
(\%)\end{array}$ & $\begin{array}{l}2035 \\
(\%)\end{array}$ \\
\hline & UK & 272 & 16 & 14 & 13 & 12 & 41 & 40 & 37 & 38 \\
\hline \multirow[t]{16}{*}{ Canada } & Belgium & 123 & 12 & 11 & 12 & 12 & 32 & 32 & 34 & 38 \\
\hline & China & 433 & 27 & 24 & 24 & 23 & 69 & 68 & 68 & 70 \\
\hline & Croatia & 21 & 17 & 16 & 17 & 17 & 43 & 46 & 48 & 53 \\
\hline & France & 401 & 13 & 13 & 13 & 13 & 34 & 35 & 36 & 40 \\
\hline & Germany & 64 & 11 & 10 & 9 & 10 & 28 & 27 & 26 & 30 \\
\hline & Indonesia & 22 & 16 & 15 & 15 & 15 & 40 & 41 & 43 & 47 \\
\hline & Japan & 275 & 12 & 12 & 12 & 13 & 31 & 34 & 35 & 39 \\
\hline & Korea & 223 & 20 & 18 & 18 & 18 & 51 & 50 & 50 & 54 \\
\hline & Netherlands & 394 & 12 & 12 & 12 & 12 & 32 & 33 & 33 & 37 \\
\hline & Poland & 34 & 18 & 17 & 17 & 16 & 48 & 48 & 48 & 51 \\
\hline & Spain & 207 & 13 & 12 & 12 & 13 & 33 & 34 & 36 & 39 \\
\hline & Switzerland & 13 & 13 & 12 & 12 & 13 & 34 & 35 & 35 & 40 \\
\hline & Trinidad and Tobago & 126 & 24 & 22 & 20 & 20 & 63 & 60 & 59 & 61 \\
\hline & Turkey & 40 & 20 & 19 & 19 & 19 & 53 & 53 & 54 & 58 \\
\hline & USA & 239 & 13 & 12 & 13 & 13 & 34 & 35 & 36 & 40 \\
\hline & UK & 101 & 14 & 13 & 13 & 13 & 38 & 37 & 37 & 41 \\
\hline \multirow[t]{5}{*}{ Chile } & Bahrain & 46 & 18 & 15 & 14 & 13 & 46 & 42 & 39 & 40 \\
\hline & China & 509 & 29 & 26 & 25 & 23 & 76 & 73 & 71 & 72 \\
\hline & Indonesia & 15 & 18 & 16 & 16 & 16 & 46 & 46 & 47 & 49 \\
\hline & Japan & 76 & 14 & 14 & 13 & 13 & 37 & 39 & 38 & 40 \\
\hline & Korea & 62 & 22 & 20 & 19 & 18 & 57 & 55 & 54 & 56 \\
\hline \multirow[t]{4}{*}{ India } & China & 95 & 38 & 36 & 35 & 32 & 100 & 100 & 100 & 100 \\
\hline & Iran & 58 & 25 & 22 & 20 & 19 & 66 & 62 & 58 & 60 \\
\hline & Japan & 41 & 22 & 23 & 22 & 21 & 58 & 63 & 64 & 66 \\
\hline & Korea & 11 & 31 & 29 & 28 & 27 & 80 & 81 & 81 & 83 \\
\hline Indonesia & China & 30 & 28 & 25 & 25 & 23 & 72 & 71 & 71 & 70 \\
\hline \multirow[t]{2}{*}{ Kazakhstan } & China & 30 & 31 & 26 & 24 & 23 & 80 & 74 & 69 & 70 \\
\hline & Russia & 374 & 23 & 20 & 19 & 18 & 59 & 55 & 53 & 57 \\
\hline \multirow[t]{3}{*}{ Malaysia } & China & 445 & 33 & 30 & 28 & 26 & 87 & 83 & 80 & 80 \\
\hline & Indonesia & 29 & 22 & 20 & 19 & 18 & 56 & 55 & 55 & 57 \\
\hline & Switzerland & 23 & 19 & 17 & 16 & 16 & 50 & 48 & 46 & 49 \\
\hline \multirow[t]{3}{*}{ Mongolia } & China & 207 & 40 & 36 & 36 & 34 & 105 & 101 & 103 & 104 \\
\hline & Hong Kong & 10 & 27 & 23 & 23 & 22 & 70 & 65 & 66 & 69 \\
\hline & Singapore & 10 & 35 & 30 & 28 & 26 & 91 & 85 & 81 & 79 \\
\hline Netherlands & Canada & 12 & 12 & 11 & 11 & 11 & 30 & 31 & 31 & 34 \\
\hline \multirow[t]{2}{*}{ Norway } & Netherlands & 138 & 14 & 12 & 11 & 10 & 36 & 34 & 30 & 30 \\
\hline & UK & 26 & 16 & 14 & 12 & 11 & 41 & 38 & 34 & 34 \\
\hline \multirow[t]{3}{*}{ Oman } & India & 61 & 28 & 22 & 18 & 15 & 73 & 60 & 51 & 48 \\
\hline & Qatar & 27 & 28 & 17 & 11 & 8 & 73 & 46 & 31 & 24 \\
\hline & Saudi Arabia & 197 & 21 & 12 & 6 & 4 & 55 & 33 & 16 & 12 \\
\hline \multirow[t]{2}{*}{ Peru } & China & 329 & 35 & 32 & 30 & 27 & 91 & 89 & 85 & 84 \\
\hline & Japan & 19 & 19 & 19 & 18 & 17 & 50 & 53 & 51 & 51 \\
\hline Philippines & Japan & 119 & 21 & 22 & 21 & 21 & 55 & 61 & 61 & 63 \\
\hline \multirow[t]{2}{*}{ Russia } & China & 364 & 32 & 30 & 29 & 27 & 84 & 82 & 83 & 84 \\
\hline & Czechia & 30 & 22 & 21 & 22 & 21 & 57 & 59 & 62 & 64 \\
\hline
\end{tabular}


Table 5 (continued)

\begin{tabular}{|c|c|c|c|c|c|c|c|c|c|c|}
\hline & & \multicolumn{5}{|c|}{ Projection (2015 million USD) } & \multicolumn{4}{|c|}{ Relative development } \\
\hline & & 2015 & $\begin{array}{l}2020 \\
(\%)\end{array}$ & $\begin{array}{l}2025 \\
(\%)\end{array}$ & $\begin{array}{l}2030 \\
(\%)\end{array}$ & $\begin{array}{l}2035 \\
(\%)\end{array}$ & $\begin{array}{l}2020 \\
(\%)\end{array}$ & $\begin{array}{l}2025 \\
(\%)\end{array}$ & $\begin{array}{l}2030 \\
(\%)\end{array}$ & $\begin{array}{l}2035 \\
(\%)\end{array}$ \\
\hline & Finland & 52 & 19 & 17 & 17 & 16 & 49 & 47 & 48 & 50 \\
\hline & Germany & 24 & 16 & 14 & 14 & 14 & 41 & 40 & 40 & 42 \\
\hline & Japan & 44 & 17 & 17 & 17 & 17 & 44 & 47 & 49 & 51 \\
\hline & Korea & 11 & 25 & 23 & 23 & 22 & 65 & 64 & 65 & 67 \\
\hline & Poland & 25 & 24 & 22 & 22 & 21 & 62 & 62 & 62 & 64 \\
\hline & Romania & 15 & 24 & 22 & 22 & 20 & 62 & 60 & 62 & 63 \\
\hline & Slovakia & 106 & 25 & 23 & 23 & 21 & 65 & 65 & 65 & 65 \\
\hline & Spain & 18 & 18 & 17 & 17 & 17 & 46 & 47 & 49 & 52 \\
\hline & Turkey & 126 & 26 & 24 & 24 & 23 & 67 & 67 & 68 & 70 \\
\hline & Ukraine & 106 & 26 & 26 & 29 & 28 & 66 & 73 & 82 & 86 \\
\hline & UK & 68 & 20 & 18 & 18 & 17 & 51 & 50 & 51 & 53 \\
\hline \multirow[t]{11}{*}{ South Africa } & China & 1500 & 29 & 28 & 27 & 26 & 76 & 77 & 79 & 79 \\
\hline & Hong Kong & 108 & 17 & 15 & 15 & 15 & 43 & 43 & 44 & 46 \\
\hline & Germany & 52 & 13 & 13 & 13 & 12 & 33 & 35 & 36 & 38 \\
\hline & India & 111 & 25 & 25 & 26 & 25 & 66 & 70 & 74 & 77 \\
\hline & Italy & 71 & 12 & 12 & 13 & 12 & 32 & 34 & 36 & 38 \\
\hline & Japan & 245 & 14 & 15 & 16 & 15 & 37 & 42 & 45 & 47 \\
\hline & Korea & 302 & 22 & 21 & 21 & 20 & 57 & 59 & 61 & 63 \\
\hline & Netherlands & 132 & 15 & 15 & 15 & 14 & 38 & 41 & 43 & 45 \\
\hline & Slovenia & 19 & 18 & 18 & 18 & 18 & 46 & 50 & 53 & 55 \\
\hline & Turkey & 23 & 23 & 22 & 22 & 21 & 59 & 62 & 64 & 66 \\
\hline & USA & 15 & 15 & 15 & 16 & 16 & 40 & 43 & 46 & 48 \\
\hline South Africa & UK & 60 & 17 & 16 & 16 & 16 & 43 & 46 & 47 & 49 \\
\hline \multirow[t]{12}{*}{ Sweden } & Austria & 13 & 12 & 11 & 10 & 10 & 31 & 30 & 30 & 31 \\
\hline & Belgium & 27 & 10 & 10 & 10 & 10 & 27 & 28 & 28 & 30 \\
\hline & Egypt & 68 & 20 & 20 & 20 & 20 & 52 & 55 & 57 & 61 \\
\hline & Finland & 201 & 12 & 11 & 10 & 10 & 31 & 30 & 29 & 31 \\
\hline & France & 17 & 11 & 11 & 11 & 11 & 29 & 31 & 31 & 33 \\
\hline & Germany & 406 & 9 & 8 & 7 & 7 & 23 & 23 & 21 & 23 \\
\hline & Netherlands & 148 & 11 & 10 & 10 & 9 & 27 & 29 & 28 & 29 \\
\hline & Qatar & 125 & 21 & 15 & 13 & 11 & 54 & 43 & 37 & 35 \\
\hline & Saudi Arabia & 192 & 14 & 11 & 8 & 7 & 37 & 29 & 22 & 23 \\
\hline & Turkey & 113 & 18 & 18 & 17 & 16 & 48 & 49 & 48 & 50 \\
\hline & $\begin{array}{c}\text { United Arab } \\
\text { Emirates }\end{array}$ & 79 & 9 & 8 & 7 & 7 & 25 & 23 & 20 & 21 \\
\hline & UK & 156 & 12 & 12 & 11 & 11 & 32 & 33 & 32 & 33 \\
\hline \multirow[t]{11}{*}{ Ukraine } & Austria & 170 & 21 & 21 & 24 & 23 & 54 & 60 & 69 & 71 \\
\hline & China & 948 & 34 & 34 & 37 & 34 & 90 & 96 & 105 & 106 \\
\hline & Czechia & 214 & 24 & 26 & 29 & 28 & 62 & 72 & 83 & 85 \\
\hline & Germany & 84 & 17 & 19 & 21 & 20 & 45 & 52 & 59 & 62 \\
\hline & Hungary & 29 & 23 & 25 & 27 & 26 & 60 & 70 & 79 & 79 \\
\hline & Japan & 54 & 19 & 21 & 24 & 23 & 49 & 60 & 69 & 71 \\
\hline & Korea & 15 & 27 & 28 & 30 & 29 & 70 & 77 & 86 & 88 \\
\hline & Poland & 217 & 26 & 27 & 29 & 27 & 67 & 75 & 83 & 84 \\
\hline & Romania & 73 & 26 & 26 & 29 & 27 & 67 & 73 & 83 & 84 \\
\hline & Slovakia & 140 & 27 & 28 & 30 & 28 & 70 & 78 & 86 & 86 \\
\hline & Switzerland & 15 & 20 & 22 & 24 & 23 & 52 & 60 & 69 & 72 \\
\hline
\end{tabular}


Table 5 (continued)

\begin{tabular}{|c|c|c|c|c|c|c|c|c|c|c|}
\hline & & \multicolumn{5}{|c|}{ Projection (2015 million USD) } & \multicolumn{4}{|c|}{ Relative development } \\
\hline & & 2015 & $\begin{array}{l}2020 \\
(\%)\end{array}$ & $\begin{array}{l}2025 \\
(\%)\end{array}$ & $\begin{array}{l}2030 \\
(\%)\end{array}$ & $\begin{array}{l}2035 \\
(\%)\end{array}$ & $\begin{array}{l}2020 \\
(\%)\end{array}$ & $\begin{array}{l}2025 \\
(\%)\end{array}$ & $\begin{array}{l}2030 \\
(\%)\end{array}$ & $\begin{array}{l}2035 \\
(\%)\end{array}$ \\
\hline \multirow{4}{*}{ USA } & Turkey & 66 & 28 & 29 & 31 & 30 & 73 & 80 & 90 & 92 \\
\hline & Canada & 544 & 13 & 12 & 12 & 12 & 33 & 33 & 34 & 38 \\
\hline & China & 29 & 24 & 22 & 21 & 20 & 63 & 61 & 60 & 61 \\
\hline & Mexico & 72 & 15 & 14 & 14 & 13 & 40 & 40 & 39 & 41 \\
\hline
\end{tabular}

Table 6 Relative change in trade projections

\begin{tabular}{lllll}
\hline & 2020 & 2025 & 2030 & 2035 \\
\hline Australia & 0.69 & 0.75 & 0.73 & 0.72 \\
Bahrain & 0.44 & 0.35 & 0.29 & 0.27 \\
Brazil & 0.56 & 0.57 & 0.54 & 0.55 \\
Canada & 0.41 & 0.44 & 0.44 & 0.48 \\
Chile & 0.66 & 0.66 & 0.64 & 0.65 \\
India & 0.79 & 0.83 & 0.81 & 0.83 \\
Indonesia & 0.70 & 0.71 & 0.70 & 0.69 \\
Kazakhstan & 0.59 & 0.57 & 0.54 & 0.57 \\
Malaysia & 0.81 & 0.81 & 0.77 & 0.77 \\
Mongolia & 1.00 & 1.00 & 1.00 & 1.00 \\
Netherlands & 0.30 & 0.31 & 0.31 & 0.33 \\
Norway & 0.36 & 0.35 & 0.31 & 0.30 \\
Oman & 0.59 & 0.41 & 0.26 & 0.22 \\
Peru & 0.86 & 0.88 & 0.83 & 0.81 \\
Philippines & 0.53 & 0.62 & 0.61 & 0.63 \\
Russia & 0.67 & 0.70 & 0.71 & 0.72 \\
South Africa & 0.62 & 0.67 & 0.68 & 0.69 \\
Sweden & 0.32 & 0.32 & 0.30 & 0.31 \\
Ukraine & 0.73 & 0.84 & 0.92 & 0.93 \\
USA & 0.34 & 0.36 & 0.36 & 0.39 \\
USA & & & & \\
\hline
\end{tabular}


Open Access This article is distributed under the terms of the Creative Commons Attribution 4.0 International License (http:// creativecommons.org/licenses/by/4.0/), which permits unrestricted use, distribution, and reproduction in any medium, provided you give appropriate credit to the original author(s) and the source, provide a link to the Creative Commons license, and indicate if changes were made.

\section{References}

Akyüz KC, Yildirim I, Balaban Y, Gedik T, Korkut S (2010) Examination of forest products trade between Turkey and European Union countries with gravity model approach. Afr J Biotechnol 9(16):2375-2380

Anderson J (1979) A theoretical foundation for the gravity equation. Am Econ Rev 69(1):106-116

Anderson J (2011) The gravity model. Annu Rev Econ 3:133-60

Anderson J, van Wincoop E (2003) Gravity with gravitas: a solution to the border puzzle. Am Econ Rev 93(1):170-192

Babri S, Joernsten K, Viertel M (2017) Application of gravity models with a fixed component in the international trade flows of coal, iron ore and crude oil. Marit Econ Logist 19(2):334-351

Baier SL, Bergstrand JH (2007) Do free trade agreements actually increase members' international trade? J Int Econ 71:72-95

Batra A (2004) India's global trade potential: the gravity model approach. Indian Council for Research on International Economic Relations, working paper no. 151

Berger H, Nitsch V (2008) Zooming out: the trade effect of the euro in historical perspective. J Int Money Financ 27:1244-1260

Bergstrand J (1989) The generalized gravity equation, monopolistic competition, and the factor-proportion theory in international trade. Rev Econ Stat 71(1):143-153

Buongiorno J (2015) Monetary union and forest products trade - the case of the euro. J For Econ 21:238-249

Buongiorno J (2016) Gravity model of forest products trade: application to forecasting and policy analysis. Forestry $89: 117-126$

CEPII (2017) CEPII - research and expertise on the world economy. http:// www.cepii.fr/ CEPII/ en/welcome.asp / (accessed 2017-06-28)

Chaney T (2008) Distorted gravity: the intensive and extensive margins of international trade. Am Econ Rev 98(4):1707-1721

Deardorff AV (1984) Testing trade theories and predicting trade flows. Handb Int Econ 1:467-517

Eaton J, Kortum S (2002) Technology, geography, and trade. Econometrica 70(5):1741-1779

Evenett S, Keller W (2002) On theories explaining the success of the gravity model. J Polit Econ 110(2):281-316

Feenstra RC, Markusen JR, Rose AK (2001) Using the gravity equation to differentiate among alternative theories of trade. Can J Econ 34(2):430-447

Fouré J, Bénassy-Quéré A and Fontagné L. (2012) The great shift: macroeconomic projections for the world economy at the 2050 horizon. CEPII Working paper 2012-03
Fouré J, Bénassy-Quéré A, Fontagné L (2013) Modelling the world economy at the 2050 horizon. Econ Transit 21(4):617-654

Frankel J, Rose A (2002) An estimate of the effects of common currencies on trade and income. Q J Econ 117:409-466

Glick R, Rose A (2002) Does a currency union affect trade? The timeseries evidence. Eur Econ Rev 46:1125-1151

Head K and Mayer T (2013) Gravity equations: workhorse, toolkit, and cookbook. CEPII Working Paper No. 2013-27

Helliwell J (1998) How much do national borders matter? Brookings Institution Press, Washington D.C

Hofstede G (1994) The business of international business is culture. Int Bus Rev 3(1):1-14

Kangas K, Niskanen A (2003) Trade in forest products between European Union and the Central and Eastern European access candidates. Forest Policy Econ 5(3):297-304

Kogut B, Singh H (1998) The effect of national cultural on the choice of energy mode. J Int Bus Stud 19(3):411-432

Labson S (1997) Changing patterns of trade in the world iron ore and steel market: an economctric analysis. J Policy Model 19(3):237-251

McCallum J (1995) National borders matter: Canada-U.S. regional trade patterns. Am Econ Rev 85(3):615-623

Mayer T and Zignago S (2011) Notes on CEPII's distances measures: the GeoDist Database. CEPII Working Paper 2011-25

Olofsson C, Wadsten J and Lundmark R (2017) Renewable energy trade in Europe: efficient use of biofuels. $15^{\text {th }}$ International Associatation of Energy Economics European Conference, 3-6 September, 2017. Vienna, Austria

Peterson E, Grant J, Roberts D, Karov V (2013) Evaluating the trade restrictiveness of phytosanitary measures on U.S. fresh fruit and vegetable imports. Am J Agric Econ 95:842-858

Redding S, Venables T (2004) Economic geography and international inequality. J Int Econ 62(1):53-82

Robertson P and Robitaille M-C (2014) The gravity of resources and the tyranny of distance. The Western University of Australia, Economics Discussion Paper 15.01. Perth: Australia

Srivastava RK, Green RT (1986) Determinants of bilateral trade flows. J Bus 59(4):623-640

Stay K, Kulkarni K (2016) The gravity model of international trade, a case study: The United Kingdom and her trading partners. Amity Global Business Review 11:28-39

Tinbergen J (1962) Shaping the world economy: suggestions for an international economic policy. The twentieth century fund, New York

Trefler D (1995) The case of the missing trade and other mysteries. Am Econ Rev 85(5):1029-1046

UN-United Nations (2017) UN Comtrade Database. https://comtrade. un.org/ (accessed March-May 2017)

Wei S-J (1996) Intra-national versus international trade: how stubborn are nations in global integration. National Bureau of Economic Research, NBER working paper 5531

Zahniser SS, Pick D, Pompelli G, Gehlhar MJ (2002) Regionalism in the western hemisphere and its impact on U.S. agricultural exports: a gravity model analysis. Am J Agric Econ 84:791-797 